\title{
CAMPYLOBACTER JEJUNI OCCURRENCE IN CHICKEN FECAL SAMPLES FROM SMALL PROPERTIES IN PELOTAS, SOUTHERN OF BRAZIL
}

\author{
Fabiane R. Gomes ${ }^{1 *}$; Bruna R. Curcio ${ }^{1}$; Sílvia R.L. Ladeira ${ }^{1}$; Heriberto Fernández²; Mário Carlos Araújo Meireles ${ }^{1}$ \\ ${ }^{1}$ Faculdade de Veterinária, Universidade Federal de Pelotas, Pelotas, RS, Brasil; ${ }^{2}$ Institute of Clinical Microbiology, Universidad \\ Austral de Chile, Valdivia, Chile
}

Submitted: April 15, 2005; Returned to authors for corrections: August 09, 2005; Approved: March 26, 2006

\begin{abstract}
The aim of this study was to evaluate the occurrence of thermophilic Campylobacter species in broiler flocks from 26 small properties located near the campus of Federal University of Pelotas, RS, Brazil. A total of 404 chicken fecal samples were analyzed and after isolation, identification and biotyping was performed according to Lior's scheme. Twenty one strains (5.2\%) of Campylobacter jejuni biotype II were isolated from animals from seven properties (26.9\%), with a variation from $3 \%$ to $34.6 \%$ among the positive properties. We also analyzed twelve $C$. jejuni isolates by polymerase chain reaction (PCR), using specific primers that generate a fragment of $402 \mathrm{pb}$. Our study allowed us to observe that chickens raised in non-industrial establishments without sanitary attention can harbour $C$. jejuni in their intestinal tract, and by doing so, they could be a serious health risk to humans.
\end{abstract}

Key words: Campylobacter jejuni, thermotolerant species, diarrhea, chicken

\section{INTRODUCTION}

In the last two decades, thermophilic Campylobacter species have become recognized as one of the principal causes of human diarrhea in developed and developing countries (2). C. jejuni and $C$. coli are the most important agents that cause human enteritis and less frequently $C$. lari (28). This is a food-borne infection and the consumption of undercooked chicken meat has been identified as a significant risk factor $(2,30)$. However, other factors, such as non-pasteurized milk $(7,24)$ and contaminated water consumption $(24,25)$, as well as contact with small and farm animals $(2,24)$ have also been reported as sources of infection (26).

A great variety of mammals and wild birds can be reservoirs of thermophilic Campylobacter species, and thus potential sources of contamination for humans, animals, food and surface waters (10). The clinical manifestation of Campylobacter gastroenteritis differs between developed and undeveloped countries. In developed countries it appears as a sporadic infection while in developing countries it occurs as outbreaks
$(26,27)$. The disease is not totally understood in developing countries, probably due to the lack of obligatory notification to the agencies of public health, and to difficulties with isolation techniques found in microbiology laboratories.

In Brazil, the presence of Campylobacter spp. in acute and chronic cases of diarrhea has been reported, as well as in ansymptomatic individuals $(3,13,15,23)$. Scarcelli et al. (21) reported the isolation of $C$. jejuni in $20 \%$ of fecal and carcass chicken samples from the state of São Paulo. In a different study Scarcelli et al. (22), using the PCR technique, analyzed 74 chicken carcasses and meat samples from state abattoirs, and found 5 positive $C$. jejuni samples.

Although Campylobacter species have been isolated from chicken meat (4-6), there is not sufficient information about cases of the disease occurrence and the animal carriage of thermophilic campylobacters, especially in the Southern region of Brazil. The aim of this study was to evaluate the occurrence of thermophilic Campylobacter species in broiler flocks in 26 small properties in Pelotas, Rio Grande do Sul, Brazil.

\footnotetext{
*Corresponding Author. Mailing address: Rua 20, Sul, Lote 12, Águas Claras. 71925-360. Brasília, DF. E-mail: fabianegomes@ brturbo.com.br
} 


\section{MATERIALS AND METHODS}

\section{Material collection and culture conditions}

The material for this study was collected on 26 small farms, dedicated family agriculture and kept broiler flocks with the purpose of meat production and eggs for the consumption of the family and commercialization of the excess. The birds were of different kinds (Playmouth Roch, New Hampshire, Rode Island Red, Embrapa 41, and cross breeds), were adult, created of half-intensive form, in poor conditions of hygiene, fed with maize and occasionally with commercial feed and available water ad libitum. A total of 404 fecal chicken swabs samples were collected and transported in enrichment broth (9), to the laboratory and incubated for 24 hours, at $42^{\circ} \mathrm{C}$ under microaerobic conditions (5\% oxygen, $10 \%$ carbon dioxide), using the Microearobac system (Probac do Brazil, São Paulo, SP, Brazil). After 24 hours of culture in enrichment media, the broth cultures were spread onto modified Skirrow plates (8) and the plates incubated for 48 hours in the same conditions as described above.

\section{Characterization of the microorganisms}

The identification of presumptive Campylobacter isolates was based on colony morphology and Gram stain. Identification to the species and biotypes level was based on sensitivity to nalidixic acid and to cephalothine, growth at $25^{\circ} \mathrm{C}, 37^{\circ} \mathrm{C}$ and $42^{\circ} \mathrm{C}$, catalase and oxidase positive reactions and the biochemical tests proposed by Lior $\left(\mathrm{H}_{2} \mathrm{~S}\right.$ production, hippurate hydrolysis, DNase production) to establish the biotypes (17).

\section{Polymerase chain reaction DNA Extraction}

Colonies of Campylobacter were suspended in $100 \mu \mathrm{L}$ of sterile Milli-Q water and washed twice at $14000 \mathrm{rpm}$ for two minutes. The pellet was re-suspended in $100 \mu \mathrm{L}$ of Milli-Q water and boiled for 7 minutes. After centrifugation (14000 rpm for 7 minutes), the supernatant was used as template for PCR.

\section{DNA amplification}

DNA amplification was performed with a specific pair of primers for $C$. jejuni, based on the sequence Pdt 1720 (5 $5^{\prime} \mathrm{TGA}$ CGC TAG TGT TGT AGG AG 3'e 5'CCATCA TCG CTAAGT GCAAC 3’) (Life Technologies do Brasil Ltda, São Paulo, SP), producing a PCR product of $402 \mathrm{pb}$. The reactions were performed according to the method described by $\mathrm{Ng}$ (18), with some modifications. The total volume of the reaction was $50 \mu \mathrm{L}$, containing $0.2 \mathrm{mM}$ of each dATP, dCTP, dGTP and dTTP, $0.5 \mathrm{U}$ Taq DNA polimerase, $2 \mu \mathrm{L}$ from each primer, $2 \mathrm{mM} \mathrm{MgCl} 2$, $50 \mathrm{mM} \mathrm{KCl}, 10 \mathrm{mM}$ Tris- $\mathrm{HCl}(\mathrm{pH} 8.3)$ and $2 \mu \mathrm{L}$ DNA. The amplification was performed in a termocycler 480 (Perkin Elmer Cetus, USA) with an initial denaturation period of 3 minutes at $95^{\circ} \mathrm{C}$, followed by 25 amplification cycles (denaturation at $95^{\circ} \mathrm{C}$ for 15 seconds, annealing at $48^{\circ} \mathrm{C}$ for 15 seconds and extension at $72^{\circ} \mathrm{C}$ for 30 seconds), and extension for 10 minutes at $72^{\circ} \mathrm{C}$. The resulting product was analyzed through electrophoresis and $20 \mu \mathrm{L}$ of the PCR product was applied in agarose gel at $1.5 \%$, containing ethidium bromide $(0.01 \%)$, and running at $100 \mathrm{~V}$ for 45 minutes. The visualization was done under ultraviolet light and the results were documented using the Kodak Digital Science ID image capture system. C. coli ATCC 49941 strain was used as negative control and a molecular weight marker 800pb ladder (Amersham Pharmacia) was included.

\section{RESULTS AND DISCUSSION}

Small properties were selected for this study owing to their prevalence in the vicinity of the campus of Federal University of Pelotas. Chiken farming in this area provides subsistence foods and provision for local people.

It has been demonstrated by different authors $(4,11,14,23,24)$ that these fowl are intestinal carriers of $C$. jejuni and C. coli. In this work, $C$. jejuni was the only isolated specie from 21 samples (5.2\%), collected on 7 properties $(26.9 \%)$. Other authors $(4,16,29-31)$ have reported higher percentages, as well as different thermophilic Campylobacter species. In a similar work, Tresierra-Ayala et al. (30) isolated C. jejuni in $27 \%$ of the fecal samples of free range chickens, belonging to families of low social-economic level (Iquitos city, Peru). In another study, the same authors reported the presence of $C$. coli $(17 \%)$ and $C$. lari (10\%) in fecal samples of domestic chicken (29). Here in Brazil, Levi and Ricciardi (16) reported that $C$. jejuni was isolated in $64 \%$ of 168 fecal chicken samples, and Carvalho et al. (4) found that $42 \%$ of the samples collected in poultry meat factories were contaminated with $C$. jejuni. This bacterial species has been also found in viscera $(5,20)$ and chicken carcasses $(1,6,16,20)$, which may be contaminated with the animals feces during processing, as well as by the equipment and handling (19).

Uyttendaele et al. (31) studying the occurrence of $C$. jejuni and $C$. coli in poulty products (carcass, skin, and meat) from a Belgian supermarket network, observed that $28.5 \%$ of 733 samples collected were contaminated with these two agents. Also in the same report, Uyttendaele et al. (31) observed that products from Belgian (21.9\%), France (30.2\%), UK (54.5\%), and Italy (15.4\%) were contaminated with $C$. jejuni and C. coli, suggesting that even developed countries can have high Campylobacter contamination in poultry products.

Its possible to observe high Campylobacter spp. contamination level in properties that do not have Federal Veterinary inspection, however, the same it happens in places where it exists. Tresierra-Ayala et al. (30) reported similar contamination levels when studying samples from family producers (54\%) as well as commercial poultry farms (35\%) with Federal Veterinary inspection. 
We were not able to isolate thermotolerant Campylobacter species from 19 properties (73.08\%). However, these results do not surprise us, since Humphrey et al. (14) also reported groups of birds free of Campylobacter, suggesting that the absence of Campylobacter was due to inhibitory metabolic processes produced by the cecal microflora. Also, Scarcelli et al. (22) analyzed 74 carcass samples from abattoirs (São Paulo, Brazil) were unable to isolate any Campylobacter species, in spite of having identified 5 (6.75\%) positive samples of $C$. jejuni by PCR.

According to the scheme proposed by Lior (17), all the isolated $C$. jejuni strains belonged to biotype II. Similar results were reported by Fernández and Torres (11) in fecal samples from chicken reared in domestic environments in three regions of Chile. In another study conducted in Peru (30), biotype II was also frequent, however, biotypes I and III were also found.

The utilization of specific primers in the reaction confirmed the strains as $C$. jejuni, previously identified by their phenotypic characteristics.

The Campylobacter isolation frequency was relatively low in this study when compared with other research. However, we observed in individual properties high isolation percentages, up to $34.6 \%$ (as shown in Table 1). These results indicated that birds raised in non-industrial establishments and without sanitary attention may harbour thermophilic Campylobacter species, especially $C$. jejuni. One might consider this an important risk factor, since there is a correlation between the presence of these bacteria in poultry products and its concentration in the intestinal tract $(6,20)$.

In order to prevent the Campylobacter infection some good hygiene practices must be adopted: washing hands with soap before and after handling raw food, avoiding cross contamination with other foods, and washing the utensils immediately after use with hot water and detergent. Many studies have shown that one main source of Campylobacter contamination is water, so clean and chlorate water might reduce contamination, and by doing so reduce the amount of contaminated meat that reaches consumers (12).

Table 1. Campylobacter jejuni frequency in chicken fecal samples in Pelotas, Shouthern of Brazil

\begin{tabular}{cccr}
\hline Local & $\mathrm{N}^{\circ}$ of Samples & $\mathrm{N}^{\circ}$ of Isolations & $\%$ \\
\hline 1 & 06 & 01 & 16.7 \\
2 & 26 & 09 & 34.6 \\
3 & 14 & 04 & 28.6 \\
4 & 13 & 01 & 7.7 \\
5 & 06 & 02 & 33.3 \\
6 & 11 & 03 & 27.3 \\
7 & 30 & 01 & 3.3 \\
\hline Total & 106 & 21 & 19.8 \\
\hline
\end{tabular}

\section{RESUMO}

\section{Ocorrência de Campylobacter jejuni em amostras fecais de galinhas em pequenas propriedades de Pelotas, sul do Brasil}

O objetivo deste estudo foi avaliar a ocorrência de espécies termofílicas de Campylobacter em galinhas de 26 pequenas propriedades localizadas próximo ao campus da Universidade Federal de Pelotas, RS, Brasil. Um total de 404 amostras fecais de galinhas foram analisadas e após o isolamento, a identificação e a biotipificação foram realizadas de acordo com o esquema de Lior. Vinte e uma amostras $(5,2 \%)$ de Campylobacter jejuni biotipo II foram isoladas de animais de sete propriedades $(26,9 \%)$, com uma variação de $3,3 \%$ a $34,6 \%$ entre as propriedades positivas. Primers específicos, que geram um fragmento de 402pb, foram usados em PCR para analisar 12 isolados de $C$. jejuni. Concluímos que galinhas criadas em estabelecimentos não industriais e sem atenção sanitária, são portadoras de $C$. jejuni $\mathrm{e}$, desta forma, podem ser consideradas um fator de risco para infecção humana.

Palavras-chave: Campylobacter jejuni, espécies termotolerantes, diarréia, galinhas

\section{REFERENCES}

1. Almeida, P.F.; Serrano, A.M. Ocorrência de Campylobacter fetus subespécie jejuni em carcaças de frangos e suínos. Rev. Microbiol., 18(3), 279-283, 1987.

2. Blaser, M.J.; Taylor, D.N.; Feldman, R.A. Epidemiology of Campylobacter jejuni infections. Epidemiol. Rev., 5, 157-176, 1983.

3. Calzada, C.T.; Nakahara, L.K.; Kano, E.; Irino, K. Biotype and Lior's serogroup of Campylobacter jejuni and Campylobacter coli isolated in São Paulo, Brazil. Rev. Microbiol., 25(1), 1-5, 1994.

4. Carvalho, A.C.F.B.; Lima, V.H.C.; Pereira, G.T. Determinação dos principais pontos de risco de contaminação de frangos por Campylobacter durante o abate industrial. Hig. Alim., 16(99), 8994, 2002.

5. Carvalho, A.C.F.B.; Schocken-Iturrino, R.P.; Cama, L.F.S.A.M Isolation of Campylobacter jejuni from viscera and bile secretion of broiler chickens with diarrhea. Rev. Microbiol., 28(2),125-128, 1997.

6. Dias, T.C.; Queiroz, D.M.M.; Mendes, E.N.; Peres, J.N. Chicken carcasses as source of Campylobacter jejuni in Belo Horizonte, Brasil. Rev. Inst. Med. Trop. São Paulo, 32(6), 414-418, 1990.

7. Evans, M.R.; Roberts, R.J.; Ribeiro, C.D.; Gardner, D.; Kembrey, D. A milk-borne Campylobacter outbreak following an educational farm visit. Epidemiol. Infect., 117(3), 457-462, 1996.

8. Fernández, H. Thermophilic species of Campylobacter: bacteriological, epidemiological and pathogenical aspects. S. Paulo, 1983. [Doctoral Thesis - School of Medicine of S. Paulo - EPM].

9. Fernández, H. Increase of Campylobacter isolation rates using an enrichment medium. Rev. Microbiol., 23, 5-7, 1992.

10. Fernández, H.; Kahler, K.; Salazar, R.; Rios, M. Prevalence of thermotolerants species of Campylobacter and their biotypes in children and domestic birds and dogs in southern Chile. Rev. Inst. Med. Trop. (São Paulo), 36, 433-436, 1994. 
11. Fernández, H.; Torres, N. Campylobacter jejuni y Campylobacter coli em três grupos de gallinas de diferente origen geográfico del sur de Chile. Arch. Med. Vet., XXXII, 2, 241-244, 2000.

12. Fields, P.I.; Swerdlow, D.L. Campylobacter jejuni. Clin. Lab. Med., 19(3), 489-504, 1999.

13. Gonzalez, Z.; Fagundes Neto, U.; Fernández, J.H.; Wehba, J.; Trabulsi, L.R. Isolamento de Campylobacter fetus ssp. Jejuni em crianças normais e com diarréia. J. Pediatr. (Rio de Janeiro), 57(2), 127-129, 1984.

14. Humprey, T.J.; Lanning, D.G.; Mead, G.C. Inhibition of Campylobacter jejuni in vitro by broiler chicken caecal contents. Vet Rec., 125, 272-273, 1989.

15. Irino, K.; Kano, E.; Dias, A.M.G.; Calzada, C.T.; Neme, S.N.; Fernandes, S.A.; Nakahara, L.K. Isolamento de bactérias enteropatogênicas de coproculturas realizadas durante o período 1977-1983 na seção de Bacteriologia do Institutoo Adolfo Lutz, São Paulo. Rev. Inst. Adolfo Lutz, 44(2), 161-178, 1984.

16. Levi, A.; Ricciardi, I.D. Campylobacter fetus subsp. jejuni (C. jejuni): isolamento e caracterização de amostras obtidas em galinhas na cidade do Rio de Janeiro. Rev. Microbiol., 13(4), 332-334, 1982.

17. Lior, H. New extended biotyping scheme for Campylobacter jejuni, Campylobacter coli and "Campylobacter laridis". J. Clin. Microbiol., 20(4), 636-640, 1984.

18. Ng, L.K.; Kingombe, C.I.B.; Yan, W.; Taylor, D.; Hiratsuka, K.; Malik, N.; Garcia, M. Specific detection and confirmation of Campylobacter jejuni by DNA hybridization and PCR. Appl. Environ. Microbiol., 63, 4558-4563, 1997.

19. Ono, K.; Yamamoto, K. Contamination of meat with Campylobacter jejuni in Saitama, Japan. Int. J. Food Microbiol., 47(3), 21-219, 1999.

20. Sakuma, H.; Franco, B.D.G.M.; Fernández, H. Occurence of Campylobacter jejuni and Campylobacter coli in retail raw chicken meat and giblets in São Paulo, Brazil. Rev. Microbiol., 23(1), 13-16, 1992.

21. Scarcelli, E.; Miyashiro, S.; Piatti, R.M.; Campos, F.R.; Castro, A.G.M.; Cardoso, M.V.; Francisco, W.; Richtzenhain, L.J.; Genovez, M.E. Emprego da técnica do polimorfismo de comprimento dos fragmentos de restrição (RFLP) do produto obtido pela reação da polimerase em cadeia (PCR) do gene FLA na subtipagem de amostras de Campylobacter jejuni subesp. jejuni isoladas de frangos de corte e humanos. 16 Reunião Anual do Instituto Biológico, Arq. Inst. Biol., São Paulo, 70 (Supl. 3), 1-5, 2003.
22. Scarcelli, E.; Miyashiro, S.; Campos, F.R.; Castro, A.G.M.; Tessari, E.N.C.; Cardoso, A.L.P. Detecção de Campylobacter jejuni em carcaças e cortes de frangos pela reação da polimerase em cadeia. Hig. Alim., 19(129), 71-75, 2005.

23. Schmitz, L.G.; Inhan, T.M.; Teixeira, J.M.S.; Tanus, R.; Turnês, O; Fagundes Neto, U. Etiologia da diarréia aguda em Brasília. Rev. Paul. Pediatr., 100(37), 61-67, 1992.

24. Skirrow, M.; Blaser, M. Clinical and epidemiologic considerations. In: Nachamkin, I.; Blaser, M.J.; Tompkins, L.S. Campylobacter jejuni. Current Status and Future Trends. Washington, D.C., American Society for Microbiology, 1992. p.03-08.

25. Stehr-Green, J.K.; Nicholls, C.; McEwan, S.; Payne, A.; Mitchell, P. Waterborne outbreak of Campylobacter jejuni in Chrisrchurch: the importance of a combined epidemiologic and microbiologic investigation. N. Z. Med. J., 28(918), 356-358, 1991.

26. Tauxe, R.V. Epidemiology of Campylobacter jejuni infections in the United States and other industrialized nations. In: Nachamkin, I.; Blaser, M.J.; Tompkins, L.S. Campylobacter jejuni. Current Status and Future Trends. Washington, D.C., American Society for Microbiology, 1992, p.9-19.

27. Taylor, D.N. Campylobacter infections in developing countries. In: Nachamkin, I.; Tompkins, S.; Blaser, M. (eds): Campylobacter jejuni: Current Satatus and Future Trends. Washington, D.C. American Society for Microbiology, 1992, p.20-30.

28. Terzolo, H.R. Gênero Campylobacter. In: Temas de Microbiologia Veterinária, La Plata, Argentina: Ediciones SUR, 1996, p.259277.

29. Tresierra-Ayala, A.; Bendayán, M.E.; Bernuy, A.; Espinóza, F.; Fernández, H. Carriage of the classical thermotolerant campylobacters in healthy domestic animals from Eastern Peru. Rev. Inst. Med. Trop. (São Paulo), 37(6), 537-539, 1995.

30. Tresierra-Ayala, A.; Fernández, H.; Bendayán, M.E.; Pereyra, G.; Bernuy, A. Aislamiento de especies termotolerantes de Campylobacter en dos poblaciones de pollos criados con y sin confinamiento. Rev. Saud. Publ., 29(5), 389-392, 1995.

31. Uyttendaele, M.; de Troy, P.; Debevere, J. Incidence of Salmonella, Campylobacter jejuni, Campylobacter coli and Listeria monocytogenes in poultry carcasses and different types of poultry products for sale on the Belgian retail market. J. Food Protect., 62(7), 35-40, 1999. 